\title{
Analisis Kolaborasi Antar Profesi dalam Program Rujuk Balik BPJS Kesehatan di Kabupaten Kotawaringin Timur
}

\author{
Sutriso $^{1}$, Elsa Pudji Setiawati², Lukman Hilfi \\ ${ }^{1}$ Rumah Sakit Umum Daerah dr. Murjani Sampit, Kalimantan Tengah, \\ ${ }^{2}$ Departemen Ilmu Kesehatan Masyarakat, Fakultas Kedokteran Universitas Padjadjaran
}

\begin{abstract}
Abstrak
Peningkatan penyakit kronis pada usia lanjut berdampak pada peningkatan pembiayaan kesehatan, termasuk pembiayaan kesehatan yang harus ditanggung oleh BPJS. Sejak tahun 2014 BPJS melaksanakan program rujuk balik sebagai upaya efisiensi biaya kesehatan, namun dalam pelaksanaannya tidak sesuai harapan. Beberapa faktor mempengaruhinya, salah satunya adalah kolaborasi antar profesi. Tujuan penelitian menganalisis kolaborasi antar profesi dalam program rujuk balik BPJS di Kabupaten Kotawaringin Timur. Metode penelitan adalah kualitatif, dengan pendekatan studi kasus, paradigma konstruktivisme. Penelitian dilakukan dengan observasi lapangan dan data pelaksanaan program rujuk balik BPJS di Kabupaten Kotawaringin Timur, serta wawancara. Wawancara mendalam terhadap dua dokter spesialis, dua dokter umum, satu apoteker dan satu pegawai BPJS. Penelitian dilakukan di bulan Januari dan Februari 2017. Data dianalisis secara kualitatif, berdasarkan tema-tema sesuai kerangka pemikiran. Analisis data mendasarkan proposisi teoritis. Hasil penelitian: program rujuk balik BPJS di Kabupaten Kotawaringin Timur tidak mencapai target $(<5$ kasus/minggu), kolaborasi antar profesi dalam program rujuk balik kurang berfungsi karena beberapa faktor: pertimbangan sosial dan intrapersonal, lingkungan kerja, intitusi, kelembagaan serta interpersonal, perilaku dan sikap para profesi serta tidak adanya leader atau penengah dalam pelaksanaan kolaborasi antar profesi. Simpulan penelitian ini adalah pelaksanaan kolaborasi antar profesi kurang berfungsi, yang berdampak target Program Rujuk Balik BPJS di Kabupaten Kotawaringin Timur tidak mencapai target.
\end{abstract}

Kata Kunci : BPJS Kesehatan, Kolaborasi Antar Profesi, Program Rujuk Balik

\section{Analysis of Inter-Professional Collaboration in Program Rujuk Balik BPJS Kesehatan at Kotawaringin Timur District}

\begin{abstract}
The increasing of chronic disease in elderly group has an impact on increasing health financing, including health financing that should be defrayed by BPJS Kesehatan. Since 2014, BPJS Kesehatan has implemented Program Rujuk Balik as an effort on health cost efficiency, however the implementation was not as expected. Several factors affected the implementation, one of which was inter-professional collaboration. The purpose of this study is to analyzes inter-professional collaboration in Program Rujuk Balik BPJS Kesehatan at Kotawaringin Timur District. Research method is qualitative research, with case study approach and constructivism paradigm. Research has been done by observation on field and data of Program Rujuk Balik BPJS Kesehatan implementation in Kotawaringin Timur District and interview. In-depth interviews were performed with two specialists, two general practitioners, one pharmacist, and one BPJS Kesehatan employee. Research was performed in January and February 2017. Data were analyzed qualitatively and processed based on themes in accordance with framework. Data analysis based on theoretical proposition. Research results; Program Rujuk Balik BPJS Kesehatan in Kotawaringin Timur District was not achieve the target ( $<5$ cases/week), inter-professional collaboration in Program Rujuk Balik was less functionated due to several factors: social and intrapersonal cosideration, physical enviroment, organisational and institutional, interpersonal, affective and behavioral of professionals in supporting less effective collaboration. Conclusion of this study is the implementation of inter-professional collaboration is not fungsionaling affected Program Rujuk Balik BPJS Kesehatan in Kotawaringin Timur District did not achieve the target.
\end{abstract}

Keywords : BPJS Kesehatan, Inter-professional Collaboration, Program Rujuk Balik.

Korespondensi:

Sutriso, dr., M.Kes

Poli Umum Rumah Sakit Umum Daerah dr. Murjani Sampit, Kalimantan Tengah

Jl. H.M. Arsyad No. 65 Sampit, Kalimantan Tengah

Mobile : 08115214477

Email :dr3so@yahoo.co.id 


\section{Pendahuluan}

Terjadinya peningkatan peserta Badan Penyelenggara Jaminan Sosial Kesehatan kelompok usia lanjut menyebabkan meningkatkannya jumlah peserta BPJS yang memiliki risiko penyakit kronis. Pengobatan penyakit kronis yang dilakukan seumur hidup berdampak pada peningkatan biaya kesehatan, sehingga dibutuhkan program untuk meningkatkan efisiensi biaya kesehatan Progam rujuk balik BPJS sebagai salah satu upaya perwujudannya. Program rujuk balik BPJS merupakan pelayanan kesehatan penderita penyakit kronis dengan kondisi stabil dan masih memerlukan pengobatan yang panjang, dilaksanakan di layanan primer berdasarkan rujuk balik dari dokter spesialis, tujuannya optimalisasi dokter layanan primer, transfer of knowledge dan meningkatkan efektifitas pelayanan kesehatan. ${ }^{1}$ Cakupan penyakit rujuk balik: diabetes mellitus, hipertensi, jantung, astma, Penyakit Paru Obstruksi Kronik, epilepsi, schizoprenia, stroke dan Systemic Lupus Erythematosus. ${ }^{1}$

Penelitian tentang analisis implementasi program pengelolaan penyakit kronis BPJS Kesehatan Puskesmas di Kabupaten Sukoharjo, menunjukkan penderita yang dirujuk balik masih rendah, penderita sulit dijaring dokter keluarga sebagai pelaksana program pengelolaan penyakit kronis. ${ }^{2}$ Pada penelitian tentang analisis pelaksanaan prolanis pada dokter keluarga di Kabupaten Pekalongan, sering terjadi kekosongan obat. $^{3}$ Rendahnya rujukan balik kemungkinan disebabkan berbagai faktor, dalam penelitiaan faktor-faktor yang mempengaruhi program rujuk balik, rendahnya rujuk balik disebabkan oleh beban kerja berlebih dan waktu tidak mencukupi dokter spesialis/sub spesialis selain persepsi dokter spesialis terhadap kompetensi dan kualitas rujukan dokter umum serta kurangnya komunikasi dan koordinasi. ${ }^{4}$ Hal di atas menunjukkan kolaborasi antar profesi merupakan salah satu faktor yang memengaruhi program rujuk balik, maka tujuan dari penelitian ini adalah untuk menganalisis pelaksanan kolaborasi antara profesi dalam Program Rujuk Balik penderita penyakit kronis peserta BPJS Kesehatan di Kabupaten Kotawaringin Timur.

Fungsi kolaborasi antar profesi yang efektif dipengaruhi oleh faktor anteseden, proses dan hasil. ${ }^{5}$ Faktor-faktor tersebut merupakan sesuatu yang dapat meningkatkan maupun menghambat proses kolaborasi antar profesi. Faktor anteseden meliputi pertimbangan sosial dan intrapersonal, lingkungan fisik, serta faktor organisasional dan institusional. Dasar pertimbangan sosial berawal dari kesadaran bahwa seseorang harus membentuk suatu kelompok agar dapat bekerja secara efektif dan efisien. Pertimbangan intrapersonal juga merupakan komponen penting dalam menciptakan kolaborasi yang baik. Lingkungan kerja dan kedekatan diantara para profesional dapat memfasilitasi atau menghambat kolaborasi. Lingkungan kerja yang baik harus dapat mendukung kemampuan anggota tim kolaborasi. Institusi dan kelembagaan sangat berperan dalam mengurangi hambatan untuk kolaborasi antara profesi. Kebijakan yang diterapkan oleh suatu institusi atau kelembagaan harus dapat mendorong terciptanya kolaborasi antar profesi.
Antecedents Processes

Processes

\begin{tabular}{l} 
- Intraperpersonal \\
- Social \\
Physical enviromental \\
- Organiasional \\
- Instifusional \\
\hline
\end{tabular}

Behavioral

Alfective

- Interpersonal

Intellectual

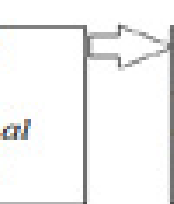

Novtus ideas

Integerative models

New trainung programs

Institutional changes
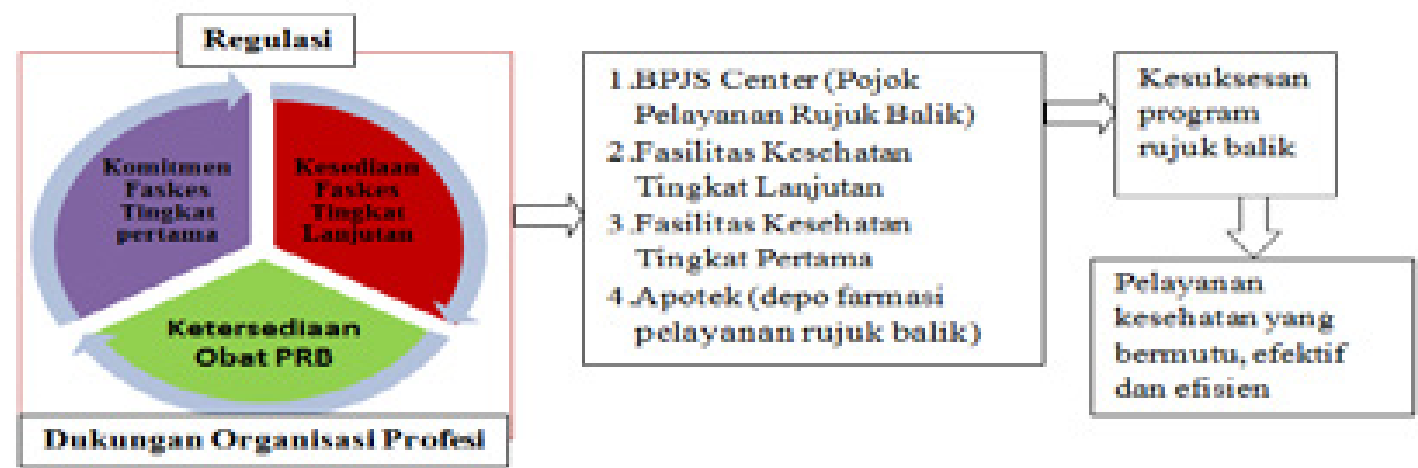

Gambar 1 Fungsi Kolaborasi Antar Profesi dalam Program Rujuk Balik 
Faktor proses meliputi faktor perilaku, faktor interpersonal dan faktor intelektual. Perilaku kolaborasi antar profesi merupakan kunci untuk mengatasi hambatan dalam proses kolaborasi. Interpersonal merupakan cara untuk berhubungan dengan orang lain, dalam hal ini adalah antar profesi. Untuk membentuk hubungan iterprofesi yang baik sangat diperlukan adanya komunikasi interprofesi yang efektif. Outcome dan Opportunity dari hasil pengembangan kolaborasi antara profesi sangat membantu dalam menciptakan ide-ide baru yang berhubungan dengan inovasi pelaksanaan program kegiatan

Program rujuk balik BPJS Kesehatan melibatkan berbagai profesi. Program tersebut didukung adanya regulasi, komitmen fasilitas pelayanan kesehatan tingkat pertama, kesediaan fasilitas kesehatan tingkat lanjut, kesediaan obat serta dukungan dari organisasi profesi. Hal tersebut menunjukkan bahwa kesuksesan program rujuk balik sangat didukung adanya kolaborasi antar profesi. Teori fungsi kolaborasi menyatakan bahwa kolaborasi akan berfungsi apabila didukung oleh beberapa faktor, baik itu faktor Antecedents, proses maupun outcome atau opportunity. Berdasarkan hal tersebut maka kerangka pemikiran penelitian ini terlihat pada gambar 1.

\section{Metode}

Metode penelitian adalah kualitatif, dengan menggunakan pendekatan studi kasus, paradigma konstruktivisme. Populasi penelitian adalah berbagai profesi yang terlibat dalam program rujuk balik BPJS Kesehatan di Kabuspaten Kotawaringin Timur. Sampel penelitian kualitatif ditetapkan secara purposive. dipilih orang yang dianggap paling tahu tentang pelaksanaan program rujuk balik yang kemudian dilakukan kriteria inklusi dan ekslusi. Kriteria inklusi pada penelitian ini adalah dokter umum, spesialis dan apoteker yang terlibat langsung dalam program rujuk balik di Kabupaten Kotawaringin Timur, yang melakukan pemeriksaan dan penanganan langsung kepada pasien, dan bekerja di layanan kesehatan yang bekerja sama dengan BPJS Kesehatan Sampit pada periode tahun 2016. Kriteria eksklusinya adalah dokter umum yang terlibat dalam program rujuk balik BPJS Kesehatan dengan keanggotaaan kurang dari dua ribu peserta, menolak untuk diwawancarai, pindah tempat kerja saat penelitian dan sulit dihubungi serta berhalangan tetap untuk diwawancari saat penelitian dan mengundurkan diri sebagai subjek penelitian.

Penelitian ini menggunakan data primer dan sekunder. Data primer dikumpulkan dari hasil observasi pelaksanaan program rujuk balik dan wawancara mendalam. Wawancara mendalam dengan menggunakan daftar pertanyaan yang telah disiapkan sebelumnya. Data sekunder diperoleh dari data dan laporan pelaksanaan program rujuk balik BPJS Kesehatan di Kabupaten Kotawaringin Timur dan telaah kepustakaan atau telaah literatur. Telaah kepustakaan dilakukan dengan cara mengumpulkan data yang ada mengenai permasalahan dalam penelitian dengan mempelajari literatur yang relevan untuk mendukung, seperti buku-buku, jurnal, internet, serta bahan-bahan yang berkaitan dengan penerapan kolaborasi antar profesi dan Program Rujuk Balik BPJS Kesehatan.

Penelitian ini telah mendapat persetujuan dari Komisi Etik Fakultas Kedokteran Universitas Padjadjaran Bandung. Penelitian dilakukan di bulan Januari dan Februari 2017 di RSUD dr. Murjani Sampit, dua Puskesmas di Sampit dan apotek Kimia Farma di Sampit.

Data hasil penelitian dianalisa secara kualitatif, diproses berdasarkan tema-tema sesuai dengan kerangka pemikiran. Tehnik analisa data mendasarkan pada proposisi teoritis. ${ }^{6}$ Analisis data yang digunakan dalam penelitian ini adalah menggunakan langkah-langkah sebagai berikut: mengolah dan mempersiapkan data untuk dianalisis, membaca keseluruhan data, memulai coding semua data serta menerapkan proses coding untuk mendiskripsikan setting, partisipan, katagori dan tema yang akan dianalisis. mendeskripsikan tema-tema ini akan disajikan kembali dalam laporan kualitatif dan membuatan interpretasi dalam penelitian kualitatif. Validitas data dilakukan untuk mempertahankan keakuratan data, dengan metode triangulasi, yaitu triangulasi sumber, triangulasi metode dan triangulasi data

Penelitian ini berpedoman pada prinsipprinsip etik, yang meliputi menghormati harkat dan martabat manusia, menghormati privasi dan kerahasiaan subyek penelitian, keadilan dan inklusivitas pemilihan responden dilakukan berdasarkan kriteria yang telah ditetapkan dan bermanfaat dan tidak merugikan.

\section{Hasil}

Profesi yang terlibat dalam Program Rujuk Balik BPJS Kesehatan di Kabupaten Kotawaringin Timur ada 20 orang, terdiri 10 dokter umum, 6 dokter spesialis dan 4 profesi lain. Capaian program rujuk balik pada tahun 2016 tidak mencapai target, yaitu kurang dari 5 kasus rujuk balik perminggu. 
Wawancara mendalam terhadap 7 responden, tetapi satu responden apoteker tidak bisa diwawancarai dikarenakan pindah tugas dan tidak bisa dihubungi. Karateristik responden dapat dilihat tabel berikut ini

Tabel 1 Karakteristik Responden

\begin{tabular}{|c|c|c|c|}
\hline Responden & $\begin{array}{l}\text { Usia } \\
\text { (tahun) }\end{array}$ & $\begin{array}{l}\text { Jenis } \\
\text { Kelamin }\end{array}$ & $\begin{array}{l}\text { Jabatan saat } \\
\text { ini }\end{array}$ \\
\hline 1 & 42 & Laki-laki & $\begin{array}{l}\text { Dokter } \\
\text { Spesialis } \\
\text { Penyakit } \\
\text { Dalam di } \\
\text { Rumah Sakit }\end{array}$ \\
\hline 2 & 43 & Laki-laki & $\begin{array}{l}\text { Dokter } \\
\text { Spesialis Jiwa } \\
\text { Rumah Sakit }\end{array}$ \\
\hline 3 & 37 & Perempuan & $\begin{array}{l}\text { Dokter Umum } \\
\text { di Puskesmas }\end{array}$ \\
\hline 4 & 32 & Perempuan & $\begin{array}{l}\text { Dokter Umum } \\
\text { di Puskesmas }\end{array}$ \\
\hline 5 & 40 & Perempuan & Apoteker \\
\hline 6 & 35 & Perempuan & $\begin{array}{l}\text { Kepala Unit. } \\
\text { Manajemen } \\
\text { Pelayanan } \\
\text { Primer BPJS } \\
\text { Kesehatan } \\
\text { Sampit }\end{array}$ \\
\hline
\end{tabular}

Wawancara mendalam terhadap 6 responden mendapatkan beberapa fenomena berkaitan fungsi kolaborasi antar profesi dalam program rujuk balik. Fenomena-fenomena yang didapat dalam penelitian ini adalah sebagai berikut beberapa responden menyatakan bahwa bahwa mereka memahami pentingnya program rujuk balik, apabila dilakukan dengan baik, akan memberikan manfaat ke semua pihak. Kondisi lain dinyatakan responden dokter spesialis bahwa pasien tidak mau dirujuk balik karena menginginkan pelayanan spesialis seperti yang diutarakannya sebagai berikut:

"Banyak pasien tidak mau dirujuk balik, maunya sama spesialis, katanya obat-obatan di puskesmas tidak lengkap, dan kalau periksa laboratorium harus ke laboratorium kesehatan daerah". (responden 1)

Ketika di tanyakan ke beberapa pasien, sebagian besar beralasan, bahwa merasa sudah terbiasa berobat dengan dokter spesialis, lebih percaya dengan dokter spesialis, juga sering tidak adanya obat di Puskesmas. Dokter spesialis menganggap, bahwa adanya keterbatasan dokter umum karena sarana atau prasarana, terkadang juga kemampuan keilmuannya sehingga dokter spesialis tidak mau merujuk balik ke dokter umum karena takut berdampak pada kondisi pasiennya, seperti yang diutarakan dokter spesialis sebagai berikut:

"Gak tahu ada pasien saya rujuk balik tapi dirujuk lagi, apa gak ada obatnya atau apa, pernah ada pasien bilang, sekali minum obat sepuluh biji, setelah saya lihat sediaannya $0,5 \mathrm{mg}$ padahal saya berikan $5 \mathrm{mg}$ sekali minum" (responden 2 )

Dokter umum menyadari adanya keterbatasan namun mereka berusaha untuk membuat diagnosis dengan benar, seperti yang diutarakan responden dokter umum sebagai berkut:

"Saya akui ada keterbatasan, tapi disamping baca buku, kan ada pelatihan-pelatihan dan memang di Puskesmas sarana penunjang pemeriksaan terbatas, seharusnya dengan rujuk balik itu kami bisa belajar" (responden 4)

Berdasarkan observasi peneliti dilapangan masih dijumpai pasien bolak balik dari apotek ke dokter spesialis. Pasien tersebut mengatakan bahwa disuruh petugas apotek untuk mananyakan resep obat ke dokternya. Ketika peneliti tanyakan kepada salah satu responden dokter spesialis menyatakan:

"Gimana, padahal saya resepkan itu obat generik atau kandungannya, mereka ngomong gak ada, kerjasamanya kurang baik, kadang pasien suruh nebus obat sekian ratus ribu rupiah, kan pasien BPJS tidak boleh ditarik, saya gak apa-apa diganti yang ada di apotek, yang penting kandungannya sama". (responden 1)

Ketika dilakukan wawancara dengan apoteker, menyatakan bahwa apoteker sudah memberitahukan obat yang tidak ada kepada dokter, seperti pernyataan berikut:

"Sudah saya sampaikan, tergantung dokternya, ada yang gak mau obatnya diganti, ada yang mau, pasiennya dijelaskan gak ngerti-ngerti". (responden 5)

Salah satu responden dokter spesialis menyatakan bahwa kondisi tentang dirinya dan pekerjaannya juga berdampak, seperti ungkapan berikut:

"Kayaknya gak cukup waktu, beban kerja, pasienbanyak, haruskepoli,keruangan, nulisresep, gimana saya harus jawab rujukan”. (responden 1)

Responden apoteker menyatakan bahwa kesadaran untuk bekerjasama dan saling membutuhkan harus ada pada setiap profesi, harus merasa sebagai tim, tidak saling menyalahkan atau tidak mau menerima pendapat dari yang lain. Apoteker juga mengatakan bahwa masalahnya tidak ada yang memediasi atau menengahi. Pemecahan masalah hanya sementara, itupun kadang tidak menyelesaikan masalah yang ada.

Sebagian besar responden menyatakan, bahwa lingkungan kerja mereka kurang memfasilitasi mereka dalam berkomunikasi, seperti yang diungkapkan responden sebagai berikut 
"Pertemuan jarang, padahal kami yang langsung menangani pasien, yang datang Kepala Puskesmas atau yang lainnya, kadang informasinya gak sampai ke kami”. (responden 3)

Menurut BPJS, bahwa pertemuan monitoring program rujuk balik tiga bulan sekali, yang datang sesuai dengan undangan. Dalam pelayanan obat terjadi permasalahan di lapangan, seperti pernyataan pihak BPJS, bahwa dokter umum atau spesialis tidak tahu proses pengadaan obat, mereka mengetahuinya obat yang ada di daftar formularium nasional ataupun daftar obat rujuk balik tersedia di apotek dan apoteker jarang memberitahukan ketersediaan obat sehingga dokter umum/ dokter spesialis tidak mendapatkan informasi yang cukup.

Beberapa responden menyatakan bahwa sepertinya intitusi tempat mereka berkerja kurang terlibat dalam program rujuk balik. Observasi di lapangan di beberapa institusi yang terlibat dalam program rujuk balik kurang memberi peran. Hal tersebut seperti peneliti lihat di rumah sakit, antara pasien rujuk biasa dengan rujuk balik diperlakukan sama. Peneliti melihat kondisi yang kontradiktif, lembar rujuk balik yang seharusnya untuk merujuk balik pasien dipakai sebagai surat kontrol pasien. Ketika didiskusikan dengan pihak BPJS menyatakan sebagai berikut:

"Nanti kita tanyakan yang di rumah sakit, apakah rumah sakit ada lembar kontrol, karena untuk pasien rujuk balik bisa memakai lembar kontrol dari rumah sakit sampai pasien dikatakan stabil atau terkontrol, setelah itu harus dirujuk balik ke dokter umum" (responden 6).

Seorang responden dokter spesialis menyatakan, bahwa seharusnya institusi membuat kebijakan untuk mempermudah kolaborasi, seperti yang diutarakan:

"Saya lihat di formulir banyak yang harus diisi, harusnya rumah sakit bikin kebijakan untuk mempermudah pengisiannya" (reponden 1)

Responden dokter umum dan dokter spesialis menyatakan bahwa kebijakan berlakunya rujukan hanya sekali, menjadi kendala dalam program rujuk balik, seperti yang disampaikan dokter spesialis:

"Belum bisa diatasi atau belum stabil, pasien harus dirujuk balik, karena surat rujukan berlaku sekali, dan biar dapat surat rujukan dokter umum" (respoden 2)

Menurut salah satu dokter spesialis bahwa terdapat pesepsi yang berbeda-beda diantara para profesi karena pernah ada pasien yang dirujuk balik tapi dirujuk lagi. Sementara dokter umum menyatakan, bahwa justru pihak rumah sakit menyuruh pasien untuk minta surat rujukan seperti yang diutarakannya sebagai berikut:

"Tidak ngerti, kadang pasien ngotot minta dirujuk, gak ada surat rujuk balik, kan gak tahu diagnosanya, kadang pasien sudah di rumah sakit, diminta tanya ke ke rumah sakit, gak mau, kan bingung apa diagnosanya". (responden 3)

Menurut pihak BPJS, bahwa kalau sudah stabil harusnya di rujuk balik, baru setelah tiga bulan dirawat di Puskesmas, baru di rujuk lagi ke rumah sakit.

Berdasarkan hasil observasi, diskusi dengan pihak BPJS dan wawancara dengan dokter umum, bahwa informasi pada formulir rujuk balik tidak diisi lengkap, kadang dokter spesialis hanya paraf dan formulir diisi perawat.

Sebagian besar responden menginginkan adanya pertemuan langsung secara rutin yang difasilitasi oleh BPJS dan IDI dalam bentuk peer review atau case review sehingga diperoleh kesepakatan tentang pengelolaan pasien, untuk pembagian wewenang antara dokter spesialis dan dokter umum serta apoteker, seperti yang disampaikan responden sebagai berikut:

"Harusnya dokter yang menangani pasien, membicarkan masalah yang terjadi, sehingga tahu tugas dan kewenangan masing-masing". (responden 4)

Sebagian besar responden menyatakan komunikasi antar mereka kurang, seperti pernyataan berikut ini:

"Kalau komunikasi secara langsung saya tidak pernah, tapi masalah terapi harusnya kalau mau ganti obat ya harusnya diskusi dulu" (responden 1)

Namun berdasarkan wawancara dengan dua reponden dokter umum menyatakan bahwa bagaimana mereka tahu terapi tidak sesuai, dimana terkadang rujuk balik sebagai media komunikasi sering kosong hanya diagnosa dan paraf dari dokter spesialis.

Beberapa responden menyadarai bahwa setiap profesi mempunyai tingkat pengetahuan dan ketrampilan yang tidak sama, seperti yang dinyatakan apoteker sebagai berikut:

"Ada perasaan takut salah memberikan rekomendasi, kompetensi keilmuannya belum mencukupi untuk diskusi dengan dokter spesialis, kami hanya memberi informasi kesediaan obat saja”. (responden 5)

Pihak BPJS menyatakan bahwa untuk mengembangkan kerjasama dalam rujuk balik, mereka membuat program inovasi pelaksanaan program. Seperti yang dinyatakanya berikut:

"Kami membuat terobosan baru, pasien yang rumahnya jauh dari apotek Kimia Farma, obat yang diresepkan oleh dokter spesialis dapat dilayanai dulu oleh dokter umum, setiap bulannya ditagihkan ke kami lewat apotek Kimia Farma". (responden 6). 


\section{Pembahasan}

Program rujuk balik BPJS di Kabupaten Kotawaringin Timur melibatkan berbagai profesi kesehatan, yang meliputi dokter umum, spesialis dan apoteker. Meskipun telah ada regulasi, dukungan organisasi profesi dan komitmen kerjasama namun target rujuk balik tidak tercapai. Beberapa penelitian juga mendapatkan rendahnya rujuk balik dan sering terjadinya kekosongan obat., ${ }^{2,3}$ Penelitian lain mendapatkan beberapa faktor menyebabkan rujuk balik rendah. ${ }^{4}$ Penelitian-penelitan tesebut tidak menjelaskan bagaimana kolaborasi antar profesi yang terlibat program rujuk balik.

Kolaborasi yang terkoordinasi antar profesi dalam melaksanakan program dapat mengoptimalkan efektifitas kinerja. ${ }^{7}$ Hasil wawancara dan observasi pelaksanaan rujuk balik BPJS Kesehatan di Kabupaten Kotawaringin Timur didapatkan beberapa fenomena. Fenomenafenomena yang ditemukan dalam penelitian ini, yang menyebabkan tidak berfungsinya kolaborasi antar profesi, yang berdampak tidak tercapainya target program rujuk balik terlihat pada tabel 2 .

Pertimbangan sosial dan intrapersonal berpengaruh terhadap terjadinya kolaborasi. ${ }^{8}$ Dasar pertimbangan sosial berawal dari kesadaran bahwa seseorang harus membentuk kelompok untuk berkolaborasi. Berbagai kendala pertimbangan sosial muncul, pasien lebih percaya pada dokter spesialis dan keterbatasan dokter umum, khususnya obat-obatan menyebabkan dokter spesialis untuk tidak merujuk balik. Dalam penelitian lain persepsi dokter spesialis atas kemampuan dokter umum menyebabkan pasien tetap dirawat di rumah sakit. ${ }^{9}$

Pertimbangan intrapersonal merupakan komponen penting, sikap kurang simpatik seharusnya tidak ada dalam kolaborasi antar profesi. ${ }^{10}$ Kekosongan obat yang sering terjadi di apotik dan sikap kurang kooperatif antara dokter spesialis dan apoteker mengakibatkan kendala program rujuk balik.

Pertimbangan intrapersonal berpengaruh terhadap seseorang atau sekelompok orang rela atau tidak melakukan kolaborasi. ${ }^{5}$ Dokter spesialis menyatakan, bahwa beban kerja yang berlebihan dan waktu yang sangat kurang mengakibat tidak sempat lagi menulis jawaban rujukan dari dokter umum.

Kolaborasi yang efektif akan tercapai apabila masing-masing profesi dalam kolaborasi harus seimbang dari segi pengetahuan, ketrampilan, maupun pengalaman. ${ }^{5}$ Keterbatasan dokter umum dalam penanganan pasien, khususnya masalah obat dan kemampuan keilmuan menyebabkan dokter spesialis tidak merujuk balik ke dokter umum. Kondisi yang sama juga dirasakan apoteker, karena keterbatasan kompetensi keilmuannya menjadikan rasa kurang percaya dalam memberi pendapat ke dokter.

Lingkungan kerja diantara para profesi dapat memfasilitasi kolaborasi. ${ }^{11}$ Pihak BPJS menyatakan bahwa pertemuan rutin monitoring setiap tiga bulan, namun demikian beberapa profesi merasa kurang dilibatkan dalam pertemuan tersebut.

Institusi berperan mengurangi hambatan kolaborasi antar profesi. Dokter spesialis berharap

Tabel 2 Fenomena-fenomena kolaborasi antar profesi dalam program rujuk balik

\begin{tabular}{|c|c|}
\hline Faktor Fungsi Kolaborasi Antar Profesi & Fenomena - Fenomena \\
\hline \multirow[t]{3}{*}{ Social and intrapersonal cosideration } & $\begin{array}{l}\text { - Persepsi spesialis atas kemampuan dokter umum menyebabkan } \\
\text { pasien tetap dirawat di rumah sakit }\end{array}$ \\
\hline & $\begin{array}{l}\text { - Pasien lebih percaya dokter spesialis \&keterbatasan dokter } \\
\text { umum }\end{array}$ \\
\hline & $\begin{array}{l}\text { - Beban kerja berlebihan \& waktu sangat kurang bagi dokter } \\
\text { spesialis }\end{array}$ \\
\hline Physical enviroment & - Lingkungan kerja para profesi kurang memfasilitasi \\
\hline \multirow[t]{2}{*}{ Organisational and institutional } & - Institusi kurang berperan mengurangi hambatan kolaborasi \\
\hline & - kebijakan surat rujukan yang hanya berlaku sekali \\
\hline \multirow[t]{2}{*}{ Interpersonal } & - Komunikasi dirasakan kurang antar profesi \\
\hline & - Tidak adanya pertemuan tersendiri antar profesi \\
\hline \multirow[t]{2}{*}{ Affective and Behavioral of Professionals } & - Persepsi tidak sama \& tidak selaras antar profesi \\
\hline & $\begin{array}{l}\text { - Persepsi terhadap mutu rujukan dokter umum menyebabkan } \\
\text { dokter spesialis tidak mau menjawab surat rujukan }\end{array}$ \\
\hline Factor leader atau penengah & - Tidak ada penengah apabila ada permasalahan \\
\hline
\end{tabular}


manajemen rumah sakit membuat kebijakan tentang rujuk balik, misalnya dalam pengisiaan format rujuk balik. Kebijakan yang diterapkan institusi mendorong terciptanya kolaborasi antar profesi. Kebijakan berupa kewenangan, tanggung jawab dan penerapan standar pelayanan. Dokter spesialis dan dokter umum merasakan kendala dengan kebijakan surat rujukan yang hanya berlaku sekali.

Persepsi profesi terhadap kolaborasi program rujuk balik bergantung pada pemahaman mereka tentang pelaksananan rujuk balik yang berjalan selama ini. ${ }^{5}$ Terjadi persepsi yang tidak sama dan tidak selaras antara dokter umum dan dokter spesialis. Dokter spesialis menganggap keterbatasan dokter umum, khususnya obat menyebabkan pasien rujuk balik di rujuk kembali ke rumah sakit, sementara dokter umum menganggap bahwa dokter spesialis yang menyuruh pasien untuk minta surat rujukan. Penelitian lain mendapatkan persepsi terhadap mutu rujukan dokter umum menyebabkan dokter spesialis tidak mau menjawab surat rujukan. ${ }^{13}$

Kesadaran untuk bekerjasama dan saling membutuhkan harus ditanamkan pada setiap profesi. ${ }^{5}$ Dokter menganggap seharusnya apotek menyediakan seluruh obat program rujuk balik, sementara apoteker menyatakan bahwa ketersediaan obat didasarkan pada informasi dari dokter, berdasarkan resep yang ditulis dokter.

Setiap profesi harus mengetahui peran profesi yang lain, sehingga mereka dapat berbagi peran sesuai dengan kompetensi masing-masing. ${ }^{5}$ Tidak adanya pertemuan tersendiri antar profesi untuk berkoordinasi membahas permasalahan yang terjadi dilapangan mengakibatkan diantara mereka tidak tahu tugas dan kewenangan masingmasing.

Komunikasi antar profesi dapat saling berbagi ide, perspektif, dan inovasi serta dapat menekan permasalahan yang mungkin terjadi. ${ }^{13}$ Komunikasi dirasakan kurang antar profesi, hanya lewat surat rujukan, surat rujuk balik atau resep dalam pelayanan obat.

Outcome dan Opportunity dari hasil pengembangan kolaborasi antara profesi membantu dalam menciptakan ide-ide baru dengan inovasi pelaksanaan program. ${ }^{5}$ Upaya telah dilakukan oleh pihak BPJS untuk meningkatkan program rujuk balik, namun kurang tersosialisasi, sehingga belum menunjukkan hasil yang diharapkan.

Hal lain ditemukan dalam penelitian ini adalah bahwa diperlukan penengah atau leader dalam pelaksanaan kolaborasi antara profesi dalam program rujuk balik. Kesenjangan yang lebar antara profesi, khususnya dokter spesialis dengan dokter umum sehingga mengakibatkan tidak berjalannya komunikasi diantara mereka. Untuk mengurangi kesenjangan tersebut perlu ada seseorang, institusi atau profesi tertentu yang dapat sebagai penengah. Peneliti berpendapat, bahwa perlu peningkatan kompetensi dan kewenangan dokter umum untuk mengurangi kesenjangan dengan dokter spesialis sehingga kesetaraan dapat terjadi. Kesetaraan sangat diperlukan untuk komunikasi dalam pelaksanaan kolaborasi. Perlu dipertimbangkan bersama pendidikan dokter layanan primer sebagai upaya peningkatan kompetensi dan kewenangan dokter umum. Kewenangan dan kompentasi baru yang didapat dari program pendidikan dokter layanan primer dapat dipakai sebagai penengah dalam penanganan masalah yang mungkin timbul dalam program rujuk balik. Sebagai ilustrasi penanganan hipertensi dengan kumungkinan komplikasi pada jantung, tentunya dokter umum harus menambah kompetensi dan kewenangannya dalam pemeriksaan EKG.

Penelitian ini bisa ditarik keseimpulan kolaborasi antar profesi dalam program rujuk balik belum berfungsi yang berdampak pada tidak tercapainya target Program Rujuk Balik BPJS Kesehatan di Kabupaten Kotawaringin Timur. Fungsi kolaborasi antar profesi tidak berjalan diakibatkan beberapa faktor yaitu: faktor pertimbangan sosial dan intrapersonal, lingkungan kerja, institusional dan organisasional, interpersonal, sikap dan perilaku para profesi serta tidak adanya juri atau penengah sebagai leadernya.

Penelitian ini memiliki keterbatasan yaitu keterlibatan peneliti dalam program rujuk balik dan faktor hubungan kedekatan peneliti dengan subjek penelitian sedikit banyak berpengaruh terhadap hasil penelitian

Saran penelitian ini upaya keberhasilan program rujuk balik di Kabupaten Kotawaringin Timur memerlukan konsolidasi antar profesi dan pihak-pihak yang terlibat, disamping sosialisasi lebih lanjut program rujuk balik oleh pihak BPJS Kesehatan Sampit.

\section{Daftar Pustaka}

1. BPJS-Kesehatan. Panduan praktis program rujuk balik bagi peserta JKN. BPJSKesehatan, 2014.

2. Novita MS. Analisis implementasi program pengelolaan penyakit kronis (Prolanis) BPJS Kesehatan pada Puskesmas di Kabupaten Sukoharjo. Thesis. Diponegoro University, 2015.

3. Sarmaulina S. Analisis pelaksanaan program pengelolaan penyakit kronis (Prolanis) BPJS 
Kesehatan pada dokter keluarga di Kabupaten Pekalongan. UNDIP E-Journal. Diponegoro University, 2016.

4. Asri W, Gatot S, Julita H. Faktor-faktor yang mempengaruhi rujukan balik pasien penderita diabetes mellitus tipe 2 peserta asuransi kesehatan sosial dari rumah sakit ke dokter keluarga. Jurnal Manajemen Pelayanan Kesehatan. 2013;16:48-52.

5. Fakultas Kedokteran Universitas Gadjah Mada. Buku acuan umum CFHC-IPE. 2014. 17-36.

6. Creswell JW. Pendekatan metode kualitatif, kuantitatif dan campuran. Yogyakarta: Pustaka Pelajar, 2016.

7. Lin CY. Improving care coordination in the specialty referral process between primary and specialty car. North Carolina Medical Journal. 2012 April;73(1): 61-2.

8. Burtscher M.J, Manser T. Team mental models and their potential to improve teamwork and safety: A review and implications for future research in healthcare. Safety Science, 2012;50(5):1344-54.

9. Harris M, Ferreira A, Moraes I, De Andrade F, De Souza D. Reply letter utilization by secondary level specialists in a municipality. In Brazil: a Qualitative Study. Revista Pan American Journal Public Health. 2007;21(2-
3): 96-110.

10. Zaenuri SH, Tunggul AP, Vitis VF RU. Analisis persepsi dan harapan dokter terhadap peran apoteker di RSUD Prof. DR. Margono Soekarjo Purwokerto. Supplemen Majalah Kedokteran Andalas. 2014;37(1):79-87.

11. Lussy MG, Mubasysyir H. Upaya manajemen rumah sakit dalam mendukung kolaborasi antara dokter umum dan spesialis di instalasi gawat darurat. Jurnal Manajemen Pelayanan Kesehatan. 2014;17(1):37-44.

12. Smith S, Khutoane G. Why doctors do not answer referral letters. South Africa Family Practice, 2009;51(1): 64-7.

13. Zwarenstein $M$, Reeves S, Russell A, Kenaszchuk C, Conn L.G, Miller K.L, Lingard L, Thorpe K.E. Structuring communication relationships for interprofessional teamwork: a cluster randomized controlled trial. (publisher unknown). 2007.

14. Rokhmah NA, Anggorowati. Komunikasi efektif dalam praktek kolaborasi interprofesi sebagai upaya meningkatkan kalitas pelayanan. J Health Studies. 2017 Maret;1(1):65-71.

15. Nasution RFH. Pengetahuan, sikap dan persepsi petugas gawat darurat terhadap keselahan medic. J Kesehatan Masyarakat Nasional. 2009 Juni;3(6):270-4. 